\title{
One of the Causes of Internet Addiction May Be Poor Sleep Quality: A Case-controlled Study
}

\section{Internet Bağımlılı̆ının Nedenlerinden Birisi de Kötü Uyku Kalitesi Olabilir: Olgu Kontrol Çalıșması}

\author{
(D) Yunus Hacımusalar, (D) Mehmet Hamamcı* , (D) Özgül Karaaslan \\ Yozgat Bozok University Faculty of Medicine, Department of Psychiatry, Yozgat, Turkey \\ *Yozgat Bozok University Faculty of Medicine, Department of Neurology, Yozgat, Turkey
}

\begin{abstract}
Objective: Internet users in the world are increasing day by day and internet addiction is becoming an important problem. The aim of this study is to investigate the effects of sleep disorder and poor sleep quality on internet addiction levels.

Materials and Methods: One hundred and four people aged between 18-65 years old who stated that they had a sleep disorder and 116 healthy controls without any known sleep disorder were included in the study. Young's Internet Addiction Test-short Form (YIAT-SF) and the Pittsburgh Sleep Quality index (PSQI) were applied to the participant via face-to-face interviews.

Results: According to the PSQI, 74 of the total of 220 participants included in the study had poor sleep quality. YIAT-SF scores of those with poor sleep quality were significantly higher than those with good sleep quality $(p<0.001)$. There was a positive correlation between PSQI and YIAT-SF scores $(r=0.310 ; p<0.001)$. In the simple linear regression analysis, PSQI scores were found to be a significant predictor of YIAT-SF scores. When a multiple regression analysis was performed, the effect of PSQI subscales scores [daytime dysfunction $(15.4 \% ; \mathrm{p}<0.001)$ and sleep disturbances $(2.2 \% ; \mathrm{p}=0.018)]$ on YIAT-SF scores was found to be $17.5 \%$.

Conclusion: According to PSQI, internet addiction levels of those with poor sleep quality were found significantly higher than those with good sleep quality. This result shows that poor sleep quality may increase the level of internet addiction by increasing internet use. Therefore, effective treatment of sleep disorders may contribute to reducing addiction, which is an important public health problem.

Keywords: Internet addiction, sleep quality, sleep schedule, Pittsburgh Sleep Quality index
\end{abstract}

Öz

Amaç: Dünyada internet kullanıcıları gün geçtikçe artmakta ve internet bağımlıı̆ı önemli bir problem haline gelmektedir. Bu çalışmanın amacı uyku bozukluğu ve kötü uyku kalitesinin internet bağımlılığı düzeyine etkilerini araştırmaktır.

Gereç ve Yöntem: Bu çalışmaya 18-65 yaşları arasında, uyku bozukluğu yaşadığını belirten 104 kişi ve bilinen herhangi bir uyku bozukluğu olmayan 116 sağlıklı kontrol dahil edildi. Katılımcılara Young Internet Bağımlılığı Testi-kısa Formu (YIBT-KF) ve Pittsburgh Uyku Kalitesi indeksi (PUKI) yüz yüze görüşme yoluyla uygulandı.

Bulgular: PUKI'ye göre, çalışmaya katılan toplam 220 katılımcının 74 'ünün uyku kalitesi kötüydü. Uyku kalitesi düşük olanların YIBTKF puanları, uyku kalitesi iyi olanlara göre anlamlı derecede yüksekti $(p<0,001)$. PUKI ve YIBT-KF puanları arasında pozitif korelasyon bulunmuştur $(r=0,310 ; p<0,001)$. Basit doğrusal regresyon analizinde, PUKI puanlarının YiBT-KF puanlarının anlamlı bir belirleyicisi olduğu bulunmuştur. Çoklu regresyon analizi yapıldığında, PUKI alt ölçek puanlarının [gündüz işlevsizliği $(\% 15,4 ; p<0,001)$ ve uyku bozukluğu $(\% 2,2 ; \mathrm{p}=0,018)]$ YIBT-KF puanları üzerindeki etkisi $\% 17,5$ olarak bulundu.

Sonuç: PUKI'ye göre, uyku kalitesi kötü olanların internet bağımlılığı düzeyleri, uyku kalitesi iyi olanlara göre anlamlı derecede yüksek bulundu. Bu sonuç, kötü uyku kalitesinin, internet kullanımını artırarak internet bağımlı̆̆ı düzeylerini artırabileceğini göstermektedir. Bu nedenle, uyku bozukluklarının etkin tedavisi, önemli bir halk sağlığı sorunu olan bağımlıı̆̆ın azaltılmasına katkı sağlayabilir.

Anahtar Kelimeler: Internet bağımlılığı, uyku kalitesi, uyku programı, Pittsburgh Uyku Kalitesi indeksi

\section{Introduction}

Sleep, which has a biological rhythm and is specially arranged with the light-dark cycle, is necessary for the body of a person to function properly $(1,2)$. Individuals with sleep disorders can perform different activities because they cannot sleep. Reading books, listening to music, watching television (TV) and using the internet are common activities used as a sleep aid (3). People with sleep disorders may have a longer time spent on social networking websites and watching TV (4). Internet use has

Address for Correspondence/Yazışma Adresi: Yunus Hacımusalar, Yozgat Bozok University Faculty of Medicine, Department of Psychiatry, Yozgat, Turkey Phone: +90 3542140609 E-mail: hacimusalar@yahoo.com ORCID-ID: orcid.org/0000-0002-1777-2707 Received/Geliş Tarihi: 02.10.2019 Accepted/Kabul Tarihi: 20.12.2019

${ }^{\circ}$ Copyright 2020 by Turkish Sleep Medicine Society / Journal of Turkish Sleep Medicine published by Galenos Publishing House. 
increased rapidly in recent years and has become an integral part of an individuals' daily life. While internet users in the world comprised 1,991 billion in 2010, this number increased to 3,385 billion in 2016. In Turkey, these statistics increased from 29 million (40\% of the population) in 2010 to 46 million in 2016 (58\% of the population) (5). Although the concept of internet addiction is a commonly used definition, it is indicated in the Diagnostic and Statistical Manual of Mental Disorders (6). Among the subjects with a need for further studies. Internet addiction is a term for the inability to prevent the over-usage of the Internet, increased need of time spent on the Internet, losing the meaning of time spent when not online, showing signs of excessive irritability, tension and restlessness when the Internet is not reached leading to deterioration of a person's business, social and family life (7). The results of the studies reporting the prevalence of internet addiction vary widely (8-11). This difference is due to the difference in the income level of the country, geographical region, the methodology of the study, scales and definitions used for screening internet addiction. The aetiology of addiction is multifactorial, and many life events can affect addiction. In addition, addiction can cause changes in the behaviour of dependent people. Problematic internet use has been reported to cause insomnia, poor sleep quality and other sleep problems (12-14). However, to the best of our knowledge, there are no studies investigating the effect of sleep disorder on the occurrence of internet addiction. In a follow-up study, it was reported that the duration of tv and internet usage before sleep was longer in patients with sleep disorders (4). Both the reward system and negative reinforcement (providing relief by eliminating a negative situation) are very important in the formation of addiction $(15,16)$. Therefore, internet use may be increasing in order to get rid of the trouble of sleeping in those with poor sleep quality. As a result, internet addiction may develop. From this point of view, we aimed to compare the levels of internet addiction of both those with and without a known sleep disorder and those with good and poor sleep quality.

\section{Materials and Methods}

\section{Subjects}

The study was conducted by face to face interviews between April 2019 and June 2019. One hundred and four people aged between 18-65 years old who stated that they had any sleep disorder and 116 healthy controls were included in the study (Figure 1). Patients with comorbid psychiatric disease (schizophrenia and other psychotic disorders, mood disorders, obsessive-compulsive disorder, anxiety disorders, attention deficit hyperactivity disorder, etc.), chronic physical disease (hypertension, Diabetes Mellitus, rheumatic diseases, oncological diseases, heart diseases, endocrine disorders, neurological diseases, etc.), pregnancy or lactation and working in a job at a night shift were excluded from the study.

\section{Evaluation Tools}

The sociodemographic data form created by the researchers, the "Young's Internet Addiction test-short form" (YIAT-SF) evaluating the internet usage habits and the questionnaire consisting of the Pittsburgh Sleep Quality index (PSQI) assessing the sleep quality were applied.

\section{Sociodemographic Data Form}

The form consisted of questions which were prepared by the researchers including age, gender, marital status, education level, occupation, presence of psychiatric or physical chronic disease and alcohol-substance abuse.

\section{Young's Internet Addiction Test-short Form}

YIAT-SF, which was developed by Young (17) and converted into a short form in 2013 by Pawlikowski et al. (18) consists of 12 items. Kutlu et al. (19) performed the Turkish validation and reliability of the test. It is a five-point Likert-type scale (1=never, $5=$ very frequent). High scores obtained from the scale in the YIAT-SF indicate that the level of internet addiction is high.

\section{Pittsburgh Sleep Quality Index}

The PSQI was developed by Buysse et al. (20), its Turkish validation and reliability were performed by Ağargün et al. (21). The PSQI is a 19-item self-report scale that assesses sleep quality and disorder over the past month. It consists of 24 questions in total; 19 questions rely on the statements of individuals, while five questions require answers from the spouse or partner. The 18 questions with the scoring of the scale consist of seven components. These subcomponents consist of subjective sleep quality, sleep latency, sleep duration, habitual sleep efficiency, sleep disturbances, use of sleeping medication and daytime dysfunction. Each component is scored from 0 to 3 points. The total score of the seven sub-components forms the total score of the scale. The PSQI has a value of 0-21 points in total. High values indicate poor sleep quality and a high level of sleep disorder. PSQI scores of five or less are considered as good sleep quality, and those over five are considered as poor sleep quality. The individuals who agreed to participate in the study were informed about the study and were asked to provide their electronic informed consent. The data collection process was performed in accordance with the rules of the Declaration of Helsinki. The study was approved by the University Ethics Committee (2017-KAEK-189_2019.4.17_12). All participants

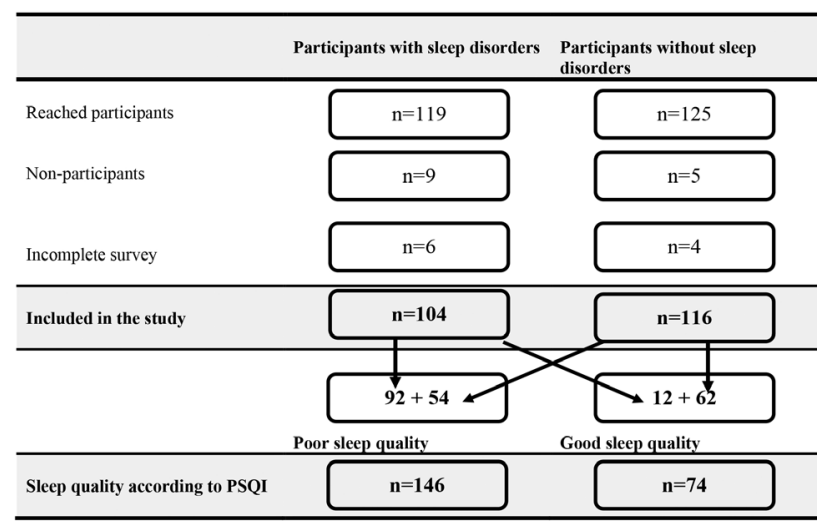

Figure 1. Flow chart of participants 
were informed that their information was coded and was kept confidential.

\section{Statistical Analysis}

The SPSS 22.0 package program (Statistical Package for Social Sciences, IBM Inc., Chicago, IL, USA) was used for the statistical evaluation. Descriptive statistics of the data were calculated, and the Kolmogorov-Smirnov test was used for the normality distribution. Categorical variables were compared with the chi-square test, variables which had normal distribution were compared with the Student's t-test, and abnormal distribution were compared with the Mann-Whitney U test. Pearson's correlation was used for data with normal distribution and Spearman's Correlation test was performed for data not showing a normal distribution. Simple linear regression analysis was used to determine whether PSQI scores were a significant predictor of YIAT-SF scores. A multiple linear regression analysis was applied to determine the effect of PSQI subscales on YIATSF scores. The significance level was considered as $p<0.05$.

\section{Results}

One hundred and four participants with sleep disorders, mean age of $34.0 \pm 12.0$ years old (min: 18, max: 62, 61 females) and 116 patients with no sleep disorder, mean age $34.1 \pm 12.5$ years old (min: 18, max: 65, 69 females) were included in the study. Other sociodemographic data of the participants are shown in Table 1. In addition, the participants were divided into two groups according to the PSQI as a good sleep quality $(n=146$, 89 females) and poor sleep quality ( $n=74,41$ females) (Table 2 ). There was no significant difference in terms of age, sex and marital status in individuals with good and poor sleep quality $(p>0.05)$. YIAT-SF scores of those with poor sleep quality were significantly higher than those with good sleep quality $(p<0.001)$ (Figure 2; Table 2). There was a positive correlation between the PSQI and YIAT-SF scores ( $r=0.310 ; \mathrm{p}<0.001)$. In the simple linear regression analysis, the PSQI scores were found to be a significant predictor of YIAT-SF scores (adjusted $\left.\mathrm{R}^{2}=0.092 ; b=0.310 ; \mathrm{p}<0.001\right)$. The increase in the PSQI scores explained $9.2 \%$ of the increase in YIAT-SF scores. When a multiple regression analysis was performed, the effect of the PSQI subscales scores [daytime dysfunction (15.4\%; $p<0.001)$, and sleep disturbances (2.2\%; $\mathrm{p}=0.018)$ ] on YIAT-SF scores was found to be $17.5 \%$ (Table 3 ).

\section{Discussion}

This is a cross-sectional, case-control study in which 220 participants participated. Studies in this area have focused on the effects of internet addiction and the use of technological devices on sleep $(12-14,22)$. Our study is important for the comparison of the levels of internet dependence according to the presence of sleep disorder and sleep quality.

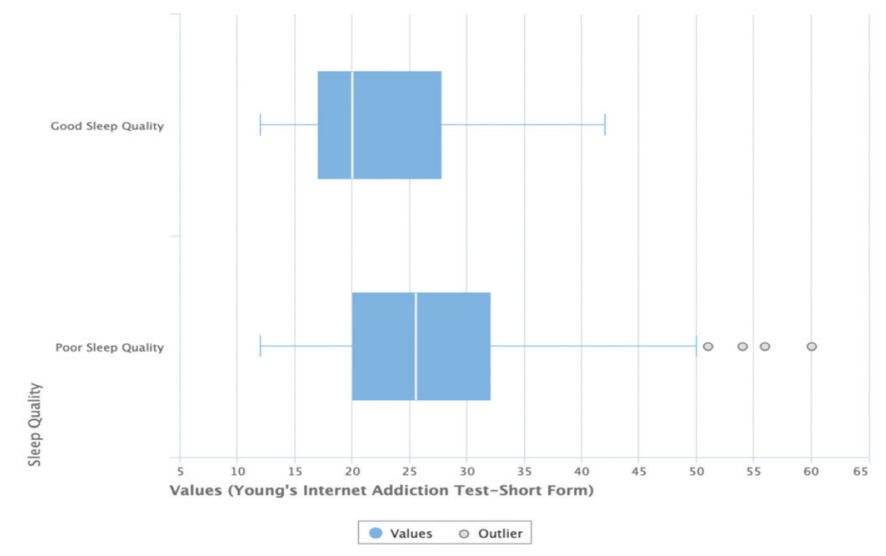

Figure 2. Internet addiction levels according to sleep quality

\begin{tabular}{|c|c|c|c|c|}
\hline & $\begin{array}{l}\text { Participants with sleep } \\
\text { disorders }(n=104)\end{array}$ & $\begin{array}{l}\text { Participants without sleep } \\
\text { disorders }(n=116)\end{array}$ & $\mathbf{t}$ & $\mathbf{p}^{\mathbf{a}}$ \\
\hline Age (years) Mean \pm SD (min-max) & $\begin{array}{l}34.0 \pm 12.0 \\
(18-62)\end{array}$ & $\begin{array}{l}34.1 \pm 12.5 \\
(18-65)\end{array}$ & 0.029 & 0.977 \\
\hline Gender & $\mathrm{n}(\%)$ & n (\%) & $x^{2}$ & $\mathrm{p}^{\mathrm{b}}$ \\
\hline Female & $61(58.7 \%)$ & $69(59.5 \%)$ & & \\
\hline Male & $43(41.3 \%)$ & $47(40.5 \%)$ & 0.016 & 0.901 \\
\hline \multicolumn{5}{|l|}{ Marital status } \\
\hline Single & $54(51.9 \%)$ & $61(52.6 \%)$ & - & - \\
\hline Married & $50(48.1 \%)$ & $55(47.4 \%)$ & 0.010 & 0.922 \\
\hline \multicolumn{2}{|l|}{ Sleep quality according to PSQI } & & $x^{2}$ & $p^{b}$ \\
\hline Good & $12(11.5 \%)$ & $62(53.4 \%)$ & - & - \\
\hline \multirow[t]{2}{*}{ Poor } & $92(88.5 \%)^{d}$ & $54(46.6 \%)$ & 43.148 & $<0.001^{* *}$ \\
\hline & Median (min-max) & Median (min-max) & $\mathrm{z}$ & $\mathrm{p}^{\mathrm{c}}$ \\
\hline Total scores of PSQI & $9.0(1-17)^{d}$ & $5.0(1-12)$ & -7.196 & $<0.001^{* *}$ \\
\hline YIAT-SF & $24(12-60)$ & $22(12-50)$ & -1.554 & 0.120 \\
\hline
\end{tabular}


Hacımusalar et al.

Poor Sleep Quality Can Cause Internet Addiction

\begin{tabular}{|c|c|c|c|c|}
\hline Sleep quality according to PSQI & $\begin{array}{l}\text { Good } \\
(n=146)\end{array}$ & $\begin{array}{l}\text { Poor } \\
(n=74)\end{array}$ & $\mathbf{t}$ & $\mathbf{p}^{\mathrm{a}}$ \\
\hline $\begin{array}{l}\text { Age (years) } \\
\text { Mean } \pm \text { SD } \\
\text { (min-max) }\end{array}$ & $\begin{array}{l}33.9 \pm 12.6 \\
(18-65)\end{array}$ & $\begin{array}{l}34.4 \pm 11.7 \\
(18-56)\end{array}$ & 0.247 & 0.805 \\
\hline Gender & n (\%) & n (\%) & $x^{2}$ & $\mathrm{p}^{\mathrm{b}}$ \\
\hline Female & $89(61.0 \%)$ & $41(55.4 \%)$ & - & - \\
\hline Male & $43(39.0 \%)$ & $33(44.6 \%)$ & 0.627 & 0.429 \\
\hline \multicolumn{5}{|l|}{ Marital status } \\
\hline Single & $75(51.4 \%)$ & $40(54.1 \%)$ & & \\
\hline Married & $71(48.6 \%)$ & $34(45.9 \%)$ & 0.142 & 0.706 \\
\hline \multicolumn{5}{|l|}{ Education level } \\
\hline Primary school & $12(8.2 \%)$ & $9(12.2 \%)$ & - & - \\
\hline High school & $57(39.1 \%)$ & $19(25.7 \%)$ & - & - \\
\hline \multirow[t]{2}{*}{ University } & $77(52.7 \%)$ & $46(62.1 \%)$ & 4.119 & 0.128 \\
\hline & Median (min-max) & Median (min-max) & z & $\mathrm{p}^{\mathrm{c}}$ \\
\hline Total scores of PSQI & $9.0(6-17)^{d}$ & $4(1-5)$ & -12.171 & $<0.001^{* *}$ \\
\hline YIAT-SF & $25.5(12-60)^{d}$ & $20(12-42)$ & -3.927 & $<0.001^{* *}$ \\
\hline
\end{tabular}

Table 3. The effect of Pittsburgh Sleep Quality index subscales scores on Young's Internet Addiction test-short form scores: Multiple linear regression analysis results with forward method

\begin{tabular}{|l|l|l|l|l|l|}
\hline & $\begin{array}{l}\mathbf{R}^{2} \\
\mathbf{( 0 . 1 7 5 )}\end{array}$ & $\mathbf{R}^{2}$ Change & $\boldsymbol{\beta}$ & $\mathbf{F}(\mathbf{d f})$ & $\mathbf{P}$ \\
\hline Daytime dysfunction & - & 0.154 & 0.336 & $39.553(1.218)$ & $<0.001^{\star *}$ \\
\hline Sleep disturbances & - & 0.022 & 0.157 & $23.034(2.217)$ & $0.018^{*}$ \\
\hline$*: p<0.005,{ }^{* *}: p<0.001$ &
\end{tabular}

In our study, internet addiction levels of participants with poor sleep quality were found to be higher than those with good sleep quality. The PSQI scores were found to be a significant predictor of the YIAT-SF scores. People with sleep disorders can perform different activities because they cannot sleep. Internet use may also be one of these activities (3). The rapid development of technology allows people to spend most of their time using the internet. Reward mechanism, positive and negative reinforcements are very important in the formation of addiction. Internet use can also cause addiction to the reward mechanism and positive reinforcements. In addition to these two mechanisms, getting rid of the restlessness caused by sleep disorder may cause internet addiction with its negative reinforcing feature $(15,16)$.

Sleep problems and deterioration in sleep quality have been reported to be higher in patients with internet addiction. Most of these studies were conducted on young people and students $(10,23-25)$. It was reported that those with high levels of internet addiction had poor sleep quality, went to bed later at night, had difficulty falling asleep, woke up more often at night and felt drowsy during the day (25). Studies have reported that internet addictions and poor sleep quality have negative influences on academic performance, life quality, relationship with friends and family in their daily life $(11,26)$. There are many factors affecting sleep quality and internet addiction. It is known that sleep disorder and internet addiction interact with each other. However, it is difficult to determine which is the triggering factor. In a three-year longitudinal study, sleep problems predicted a longer time spent watching TV and on social networking websites (4). On the other hand, neither time spent watching TV nor time spent on social networking websites predicted sleep problems. Study findings indicate that adults appear to seek out media as a means of coping with their sleep problems. However, in this study, while TV and internet usage times were measured, internet addiction levels were not evaluated. In addition, this study was conducted on university students aged 17-25 years old. Studies related to internet addiction and sleep were mostly evaluated in young adults or certain groups. The strength of this study is that it investigated the effect of sleep disturbance on internet addiction in the 18-65 age group.

\section{Study Limitations}

The most important limitations of this study were a) the cross-sectional nature of study, b) the evaluation of sleep disorder by a Self-report scale, c) non-availability of quantitative measurements such as polysomnography, d) the fact that 
despite the factors that may affect sleep disorder were tried to be excluded, not all of them could be excluded, and e) in our study, volunteers aged between 18-65 years old were included in the study. However, the Turkish validity and reliability study of YIAT-SF was conducted in university students. Therefore, the scale may not be able to evaluate the whole study group adequately. However, there is no other internet addiction scale specific to our country that can assess a wide age range, such as $18-65$ years old.

\section{Conclusion}

In this study, Internet addiction levels of those with poor sleep quality were higher than those with good sleep quality. Sleep disorder and internet addiction are an interaction. The presence of sleep disorder may increase the use of the internet and increase the level of addiction. Therefore, the effective treatment of sleep disorders may contribute to reducing dependence, which is an important public health problem.

\section{Ethics}

Ethics Committee Approval: The study was approved by the Yozgat Bozok University University Ethics Committee (2017-KAEK-189_2019.4.17_12).

Informed Consent: All participants were informed that their information was coded and was kept confidential.

Peer-review: Internally peer-reviewed.

\section{Authorship Contributions}

Concept: Y.H., M.H., Ö.K., Design: Y.H., M.H., Ö.K., Data Collection or Processing: Y.H., M.H., Ö.K.,Analysis or Interpretation: Y.H., Literature Search: M.H., Ö.K., Writing: Y.H. Conflict of Interest: No conflict of interest was declared by the authors.

Financial Disclosure: The authors declared that this study received no financial support.

\section{References}

1. Cho JW, Duffy JF. Sleep, Sleep Disorders, and Sexual Dysfunction. World J Mens Health 2019;37:261-75.

2. Maury E, Ramsey KM, Bass J. Sleep, circadian rhythms and metabolism. Metabolic Basis of Obesity 2011:229-55.

3. Exelmans L, Van den Bulck J. The Use of Media as a Sleep Aid in Adults. Behav Sleep Med 2016;14:121-33.

4. Tavernier R, Willoughby T. Sleep problems: predictor or outcome of media use among emerging adults at university? J Sleep Res 2014;23:389-96.

5. International Telecommunication Union. New data visualization on Internet users by region and country, 2010-2016 [Internet]. 2018. Available from: https://www.itu.int/en/ITU-D/Statistics/Pages/stat/ default.aspx

6. American Psychiatric Association. Diagnostic and Statistical Manual of Mental Disorders, 5th ed. Washington, DC: American Psychiatric Association, 2013.

7. Young KS. Internet addiction: A new clinical phenomenon and its consequences. Am Behav Sci 2004;48:402-15.

8. Leung L. Net-Generation Attributes and Seductive Properties and Internet Addiction. Cyberpsychology Behav 2004;7:333-48.
9. Bakken IJ, Wenzel HG, Gotestam KG, Johansson A, Oren A. Internet addiction among Norwegian adults: A stratified probability sample study. Scand J Psychol 2009;50:121-7.

10. Jahan SM, Hossain SR, Sayeed UB, Wahab A, Rahman T, Hossain A. Association between internet addiction and sleep quality among students: a cross-sectional study in Bangladesh. Sleep Biol Rhythms 2019;17:323-9.

11. Cheng C, Li AY. Internet Addiction Prevalence and Quality of (Real) Life: A Meta-Analysis of 31 Nations Across Seven World Regions. Cyberpsychol Behav Soc Netw 2014; 17:755-60.

12. Lam LT. Internet Gaming Addiction, Problematic Use of the Internet, and Sleep Problems: A Systematic Review. Curr Psychiatry Rep 2014;16:444.

13. Brunborg GS, Mentzoni RA, Molde H, Myrseth H, Skouverøe KJ, Bjorvatn $B$, Pallesen $S$. The relationship between media use in the bedroom, sleep habits and symptoms of insomnia. I Sleep Res 2011;20:569-75.

14. Lin PH, Lee YC, Chen KL, Hsieh PL, Yang SY, Lin YL. The Relationship Between Sleep Quality and Internet Addiction Among Female College Students. Front Neurosci 2019;13:599.

15. Eşel E, Dinç K. Neurobiology of Alcohol Dependence and Implications on Treatment. Turk Psikiyatri Derg 2017;28:51-60.

16. Koob GF. Neurobiology of Addiction. Focus (Madison) 2011;9:55-65.

17. Young KS. Caught in the net: how to recognize the signs of Internet addiction--and a winning strategy for recovery [Internet]. New York: John Wiley \& Sons; 1998. Available from: https://www. wiley.com/ en-us/Caught+in+the+Net\%3A+How+to+Recognize+the+Signs+of+ Internet+Addiction+and+a+Winning+Strategy+for+ Recovery-p-9780471191599

18. Pawlikowski M, Altstötter-Gleich C, Brand M. Validation and psychometric properties of a short version of Young's Internet Addiction Test. Comput Human Behav 2013;29:1212-23.

19. Kutlu M, Savcı M, Demir Y, Aysan F. Turkish adaptation of Young's Internet Addiction Test-Short Form: a reliability and validity study on university students and adolescents. Anatol J Psychiatry 2015;17:69-76.

20. Buysse DJ, Reynolds CF 3 rd, Monk TH, Berman SR, Kupfer DJ. The Pittsburgh Sleep Quality Index: a new instrument for psychiatric practice and research. Psychiatry Res 1989;28:193-213.

21. Ağargün MY, Kara H, Anlar Ö. The Validity and Reliability of the Pittsburgh Sleep Quality Index. Turkish Journal of Psychiatry 1996;7:107-15.

22. Wang PY, Chen KL, Yang SY, Lin PH. Relationship of sleep quality, smartphone dependence, and health-related behaviors in female junior college students. PLoS One 2019;14:e0214769.

23. Zhang MWB, Tran BX, Huong LT, Hinh ND, Nguyen HLT, Tho TD, Latkin C, Ho RCM. Internet addiction and sleep quality among Vietnamese youths. Asian J Psychiatr 2017;28:15-20.

24. Canan F, Yildirim O, Sinani G, Ozturk O, Ustunel TY, Ataoglu A. Internet addiction and sleep disturbance symptoms among Turkish high school students. Sleep Biol Rhythms 2013;11:210-3.

25. Ekinci Ö, Çelik T, Savaş N, Toros F. Association Between Internet Use and Sleep Problems in Adolescents. Noro Psikiyatr Ars 2014;51:122-8.

26. Bhandari PM, Neupane D, Rijal S, Thapa K, Mishra SR, Poudyal AK. Sleep quality, internet addiction and depressive symptoms among undergraduate students in Nepal. BMC Psychiatry 2017;17:106. 